\title{
Development of Filament Winding Machine for Producing Round Shapes with Different Fiber Reinforcements
}

\author{
Farklı Elyaf Takviyeleri ile İçi Oyuk Şekiller Üretmek İçin Elyaf Sarma Makinesi \\ Geliştirmesi
}

\author{
Özkan ÖZBEK ${ }^{* 1, a}$, Ali KILIÇ⿻, ${ }^{2, b}$ Ömer Yavuz BOZKURT ${ }^{2, c}$ \\ ${ }^{1}$ Kilis 7 Aralı University, Faculty of Engineering and Architecture, Mechanical Engineering Department, 79000, Kilis, Turkey \\ ${ }^{2}$ Gaziantep University, Faculty of Engineering, Mechanical Engineering Department, 27310, Gaziantep, Turkey
}

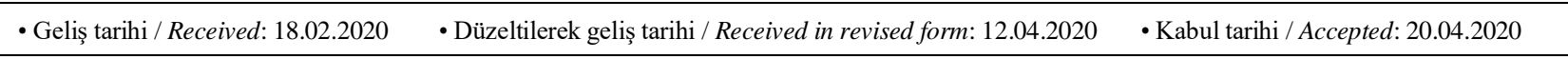

\begin{abstract}
In recent years, fiber reinforced composite structures have become an important engineering subject because they are preferred due to their high strength / weight and stiffness / weight ratios in many industrial fields such as aerospace, construction, defense, aviation, automotive and energy. Although different methods are present to produce of these materials, the most reliable way is the filament winding technique. The basic principle of the filament winding technique is based on that the fiber reinforcement impregnated by resin is wrapped on a rotary mandrel using carriage translation and mandrel rotation motions. In this study, a filament winding machine having 2 -axis motion was designed and constructed for the fabrication of different types of fiber reinforced composite pipes. The machine is capable of producing specimens in different design parameters such as dimensions up to $750 \mathrm{~mm}$ length and $250 \mathrm{~mm}$ diameter, different winding angles for hoop, helical and polar winding types. The fiber reinforced specimens were manufactured according to different winding angles, fiber reinforcements and cross sections.
\end{abstract}

Keywords: Composite Materials, Construction and Control of Winding Machine, Design, Filament Winding

$\ddot{O} z$

Son ylllarda, elyaf takviyeli oyuk kompozit yapılar, havacılı, inşaat, savunma, uzay, otomotiv ve enerji gibi birçok endüstriyel alanda sağladıkları yüksek dayanım/ağırlı ve direngenlik/ağırlı oranlarından dolayı tercih edilmeleri nedeniyle önemli bir mühendislik konusu haline geldi. Bu malzemelerin üretilmesinde farkl yöntemler mevcut olmasina rağmen, en güvenilir yöntem filament sarım tekniğidir. Filament sarım tekniğinin temel prensibi, reçine ile emprenye edilen elyaf takviyesinin, taşlyıcı çeviri ve mandrel dönüş hareketleri kullanılarak döner bir mandrel üzerine sarllmasıdır. Bu çallşmada, farkl tiplerde fiber takviyeli kompozit boruların üretimi için 2 eksenli harekete sahip bir filaman sarma makinesi tasarlandı ve üretildi. Makine, numunelerin $750 \mathrm{~mm}$ uzunluğa ve $250 \mathrm{~mm}$ çapa kadar boyutlar, sarmal, kasnak ve kutup sargı tipleri için farklı sarım açıları gibi farkl tasarım parametrelerinde üretme kabiliyetine sahiptir. Elyaf takviyeli örnekler, farklı sarım açıları, elyaf takviyeleri ve enine kesitlere göre üretildi.

Anahtar Kelimeler: Kompozit Malzeme, Sarma Makinesi Kurulumu ve Kontrolü, Tasartm, Elyaf Sarma

\footnotetext{
*a Özkan ÖZBEK; ozkanozbek@kilis.edu.tr, Tel: (0541) 619 46 35, orcid.org/0000-0003-1532-4262

${ }^{\mathrm{b}}$ orcid.org/0000-0002-3241-9944 $\quad{ }^{\mathrm{c}}$ orcid.org/0000-0003-0685-8748
} 


\section{Introduction}

In recent years due to high specific strength, good fatigue resistance, better damping and high resistance to corrosion, polymer based composite materials have attracted the attention of scientific world and commercial material developers as an alternative material to classical engineering materials (Gemi et. al., 2019; Gemi et al., 2020; Bulut, 2020). In parallel, the use of fiber reinforced composite pipes, tubes, shafts and pressurized vessels have increased in many industrial applications such as aerospace, civil, defense, aviation, automotive, energy. There are several methods to produce these fibers reinforced structural components, however due to the flexibility on fiber placement according to winding pattern, the most reliable way is the filament winding method (Özbek and Bozkurt., 2019). The main working principle of the method is based on wrapping of resin-impregnated fiber on a rotary mandrel using carriage movements.

In the market, there are several commercial filament winding machines found with different structural designs. The concept of filament winding and the first filament winding machine was presented in early 1940s to manufacture of rocket motor body (Peters, 2011). With the advancement in computers and numerical control systems, several studies about the design and fabrication of the multi-axial filament winding machines are seen in the literature. Saad (1997) designed and fabricated a filament winding machine. The machine is suitable for monofilament winding and used to manufacture the cylindrical specimens. Imamura et al. (1999) designed a filament machine to control tension system. PID and I-PD systems were proposed as the winding tension control systems. Abdalla et al. (2007) constructed a lathe type filament winding machine to fabricate glass/polyester fiber reinforced composite pipes. Lead screw mechanisms and servo motors were used to drive carriage. Mutasher et al. (2012) built a small-scale machine having the winding angle capability between $40^{\circ}$ and $80^{\circ}$. The lead screw system was installed for the movement of carriage system. Krishnamurthy and Idkan (2014) developed a low-cost filament winding machine based on the concept of engine lathe. However, the products of the machine had poor surface quality, inaccurate winding pattern and rough fiber placement. Quanjin et al. (2019) designed and constructed the portable 3-axis filament winding machine. It was reported that the machine had a good winding capability offering $\quad 0.83-1.13 \mathrm{~mm}$ circular accuracy with $1.75-3.13 \%$ standard deviation. Also, winding angle quality had the $2.25-8.68 \%$ standard deviation range. Mateen et al. (2018) also designed and developed a 2-axis filament winding machine to produce pipe samples with 50 $\mathrm{mm}$ internal diameter and $1 \mathrm{~m}$ length.

The quality of products fabricated using filament winding technique mainly depends on the design of winding pattern and accurate fiber placement. The winding pattern generation is a know-how mystery for commercial machines and pattern generator software. In this study, a laboratory scale filament winding machine having 2-axis motion was designed and constructed for the fabrication of fiber reinforced composite open and closed form structures. The main motivation of developing this machine is the generation of novel winding patterns for special purpose researches about effect of winding pattern on filament winding procedure. The machine has capability for the specimen fabrication using different design parameters such as dimensions up to $750 \mathrm{~mm}$ length and $250 \mathrm{~mm}$ diameter for cylindrical and round shapes, winding angles for helical, hoop and polar winding patterns, and the hybrid fiber placement up to three different fiber reinforcements. An algorithm on MATLAB programming environment was developed to obtain motion codes. The fiber reinforced cylindrical and round shape specimens were manufactured according to different winding angles and fiber types.

\section{Filament Winding Technique}

\subsection{About Technique}

In order to obtain polymer-based composite materials, several fabrication techniques such as hand layup, autoclave, vacuum-assisted resin transfer molding, resin transfer molding, pultrusion are present in the literature (Kim et al., 2020; Özbek and Bozkurt, 2019). Among these methods, filament winding, as shown in Figure 1, is preferred for obtaining products with hollow geometry (pipe, pressure tank, profile etc.). Nowadays, it is used for high pressure vessels, sewer pipe systems, high pressure piping systems, water tanks, large underground tanks (for oil, salt, acid, alkali, water etc.), oxygen and fire extinguisher tubes for firemen, helicopter rotor, golf clubs, wind turbine blades, transmission shafts, bus shafts, aircraft body parts, ship body parts, space shuttles (Gay, 2014). 


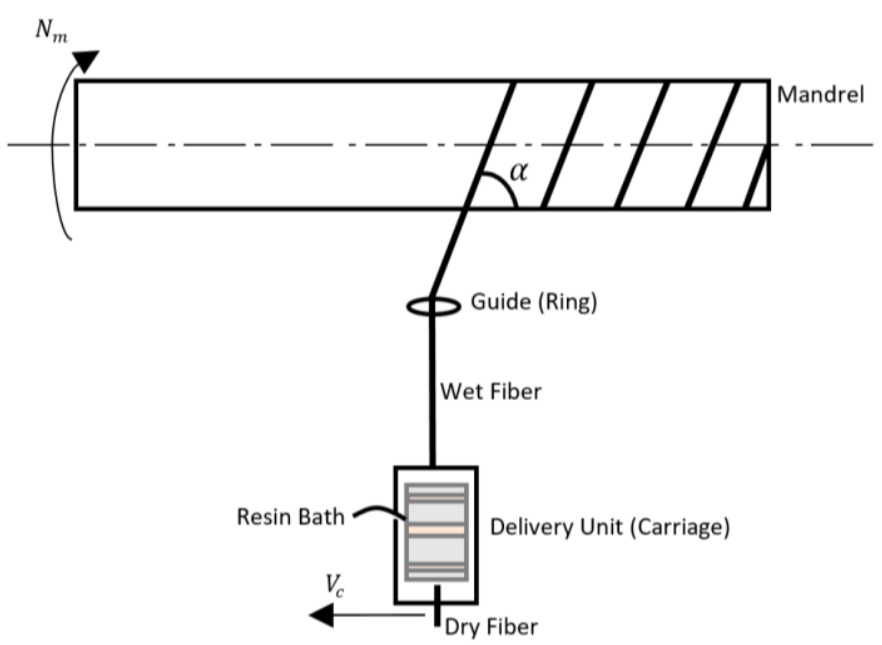

Figure 1. Filament winding technique

The composite pipe samples fabricated by filament winding technique consists of two different phase as fiber reinforcement and resin matrix. The employment of technique provides for opportunity to rule different design parameters such as winding angle, fiber type, mandrel diameter, mandrel type, resin type and density. The required design according to the field of application is easily passed on with the specified parameters. Also, the method presents the advantages such as obtaining same fiber orientations on layers and regions, connectionless fiber can be used as a single piece, the absence of high cost as in an autoclave, allowing production of large amounts of product, high fiber volume can be obtained, having faster production compared to other fabrication techniques of composite materials.

Different application methods of filament winding such as resin bath-based impregnation, wet- and dry-type winding, electrostatic depositing, prepreg winding and laser assisted impregnation are present in literature. Resin bath-based impregnation are commonly used in thermosetting industrial applications. Prepreg winding is preferred in high sensitivity applications since it has high cost. Unlike prepreg winding, wet filament winding has low cost, rapid fabrication and allowance to change resin content. Because of that; it has wide commercial applications. In the wet filament winding method, two different applications are seen to resin impregnation. These are fiber immersion that the fiber is completely immersed into resin and drum type that impregnated fiber passes on a drum. Applications are determined according to used fiber type. For example; drum type is used for carbon fiber that has easy to damage but fiber immersion is preferred for glass and aramid type fiber. Also, resin viscosity and curing temperature are important factors that affect the application selection except that fiber material types.

\subsection{Winding Patterns}

There are mainly three types of winding patterns that can be applied on filament winding method. These are called as hoop, helical and polar windings that have been classified according to winding angle, $\alpha$ which makes with longitudinal axis as shown in Figure 2. The fabrication having the winding angle approaches to $90^{\circ}$ is called as hoop or circumferential winding process. Helical winding has the constant mandrel rotation when carriage unit is moving with a linear motion in forward and backward. Polar winding is generally used for fabrication of high pressure vessels since the fiber is wrapped from one end directly to another on the mandrel. The angles having close ones to $0^{\circ}$ are required in this pattern.
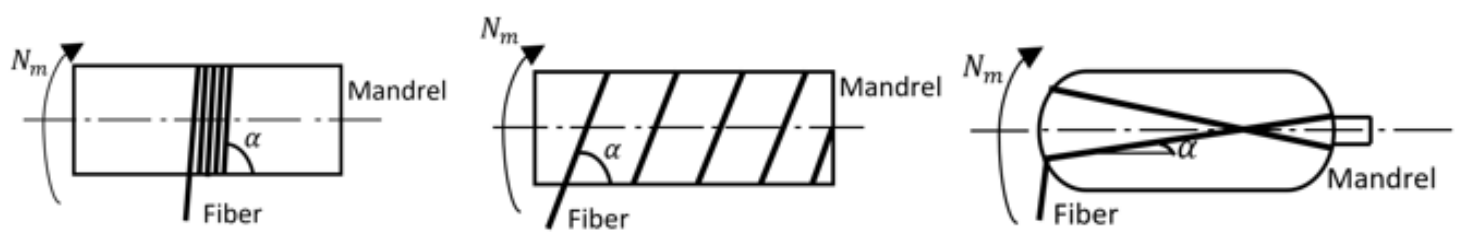

Figure 2. Winding patterns 


\section{Machine Design and Construction}

The design of machine was based on the three main parts which are mechanical part, electronic part and software part. The 2-axes movements for automated machine are linear for filament delivery and rotation for filament winding units. The machine body is made of fully 6061 Aluminum material. It has $1280 \times 1300 \times 700 \mathrm{~mm}$ dimensions in height, wide, depth and its production capacity is $750 \mathrm{~mm}$ in length and 250 $\mathrm{mm}$ in diameter. Also linear axis of the machine can reach $8000 \mathrm{~mm} / \mathrm{min}$ and rotational axis can reach $250 \mathrm{rpm}$. Details of the developed machine can be seen following sections.

\subsection{Mechanical Part}

The mechanical part of the machine consists of the five basic parts which are main structure, carriage (fiber delivery) unit, resin bath, control box and rotary unit. The main structure provides the stability and continuity entire the process. It supports the all system by balancing at certain levels and prevents the possible vibrations to ensure system working without problem.

The carriage unit helps to determine filament path with linear motion on the machine. Its motion is provided by stepper motor by using belt and pulley system. Fiber is directed to rotary unit by using a guide arranged on the carriage unit. This is the last fiber transition before winding. Also, it includes the resin bath and so can be protective for it.

Resin bath has a crucial importance for production of composites. It controls the tension guides by brass and delrin rollers which are placed inside the tank and wetting the fiber reinforcements entire the process. Tensional forces and excess resin back into the bath are given by these rollers. Also, the bath has three inlet and outlet ceramic rings which means the three filament by following different paths can be used within the same winding process.

Control box consists of required electronic components such as stepper motor drivers, limit switches, power supply, main board, cooling fans, control screen and stepper motors. All electronic components are positioned in this box.

Rotational movements for the mandrel are conducted on the rotary unit of the machine. The unit has mandrel chucks to hold the mandrel and belt-pulley system to rotate the mandrel. The filament is wrapped with a desired winding angle which is managed by relationship between carriage linear motion and mandrel rotation. Figure 3 presents the designed machine, CAD generated image and important components of the machine. The final photograph of the machine can be seen in Figure 4.

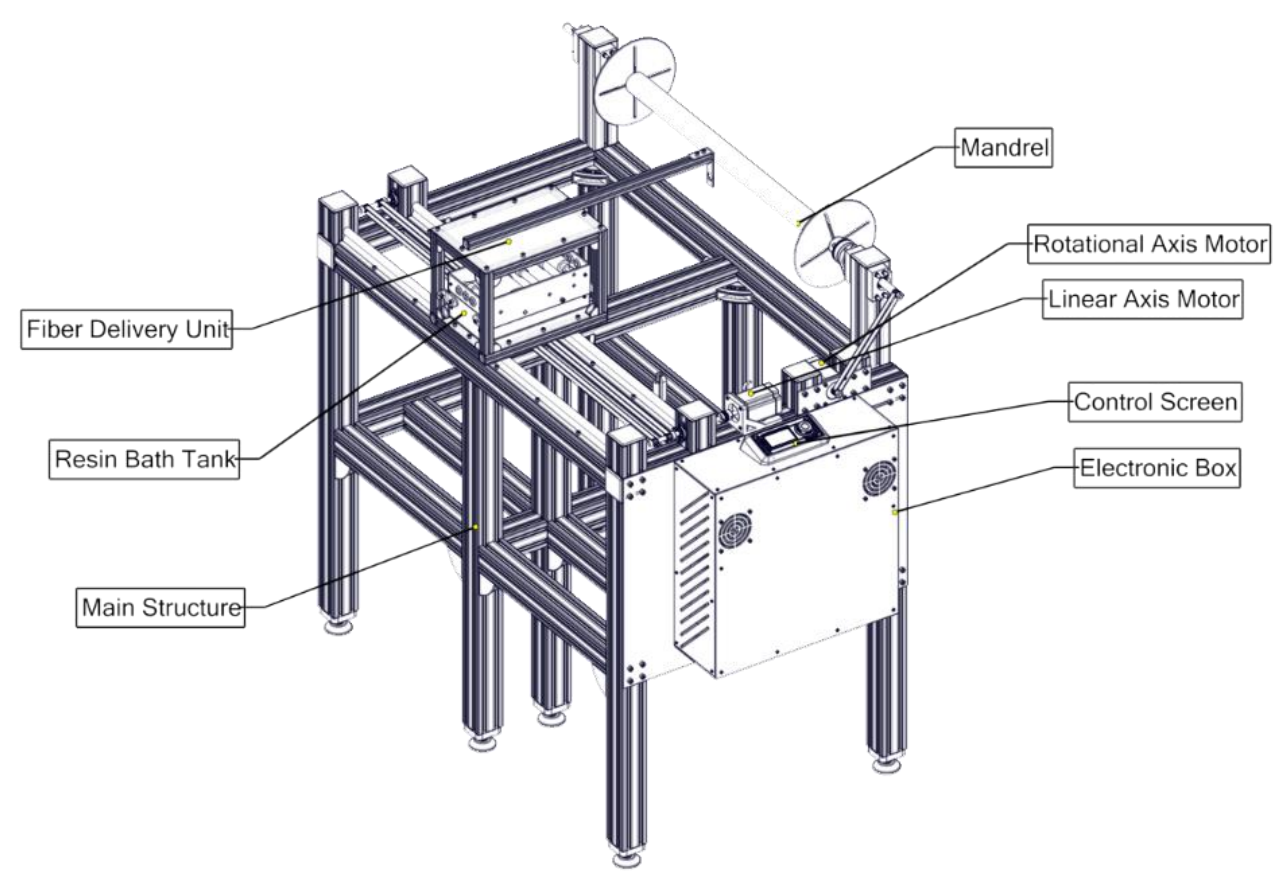

Figure 3. Main components of the filament winding machine 


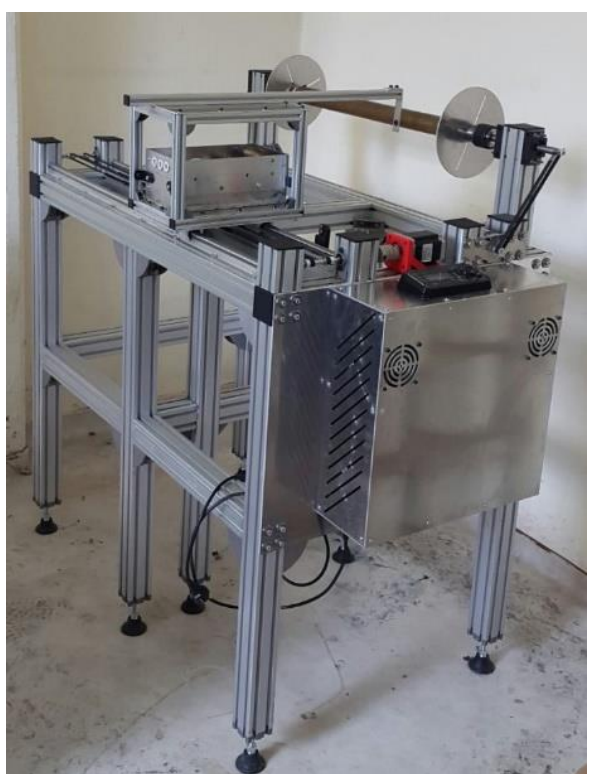

Figure 4. Final photograph of the filament winding machine

\subsection{Electronic Part}

Electronic system of the machine provides high accuracy motion by using generated G-codes. It is designed as two axis and one axis for linear motion in order to pose fiber delivery unit. Second axis is rotational axis in order wind fiber on round shapes. To actuate axes two Nema 23 size stepper motors are used with stepper drivers. Winding machine controlled by low cost but highly stable main control board. Machine movements accomplished by generated G-Code and user can control machine by using embedded screen. 4 different limit switches are used in order to prevent axes damage and collisions. Two speed controlled fans are used to cool electronic components. $12 \mathrm{~V}$ and $29.5 \mathrm{~A}$ power supply is powering the whole system. Electronic components and their relations can be seen in Figure 5.

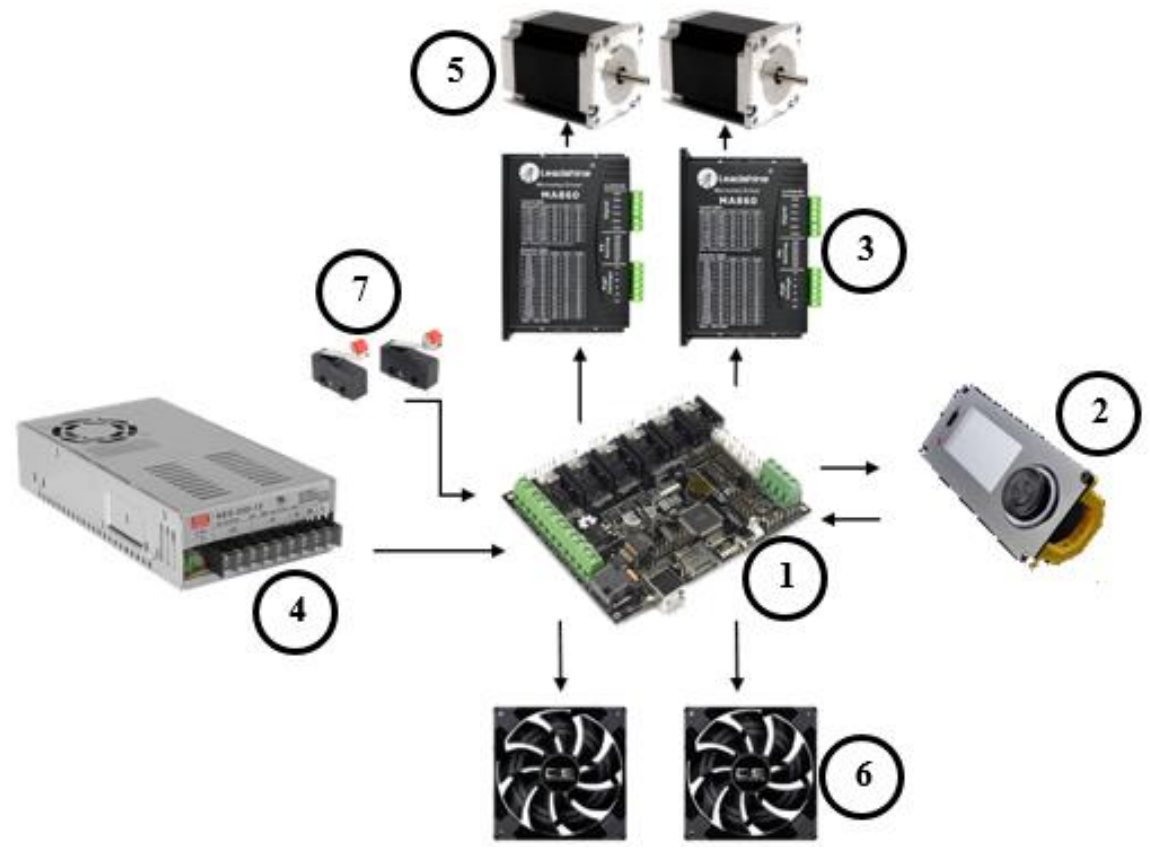

Figure 5. Electronic systems of filament winding machine

Electronic component list of the filament winding machine:

1) Megatronics 3.1 Main Board

2) Viki LCD 2.0

3) $2 \mathrm{X}$ Leadshine MA860 Stepper Motor Driver

4) MeanWell NES350-12 Power Supply

5) $2 \mathrm{X}$ Leadshine Nema $233 \mathrm{~A}$ Bipolar $1.8^{\circ}$ Stepper Motor

6) 2 X 12V Cooling Fan

7) $4 \times$ Limit Switch

\subsection{Software}

In order to control filament winding machine main control software is developed. Machine can be controlled by using embedded screen and also computer via USB. The system understands the motion code by using NIST RS274NGC G-code standard. The user can easily generate motion code by using winding angle, filament bandwidth, winding length, mandrel diameter and finally linear axis feed rate. After that this motion code can be easily send the machine, the software of the machine controls the axis to provide accurate winding operations. 


\section{Fabrication}

\subsection{Procedure}

To fabricate specimens on the filament winding machine, three steps are followed as preliminary preparations, process conducting and post processing. Firstly, release wax was applied on the mandrel and release agent film was wrapped. Afterwards, release wax was again applied to pull out the mandrel at the end of the winding process. The glass wool was applied to obtain smooth surface inside the specimens. Fiber(s) placements was performed by helping resin bath and rollers. By using EPIKOTE MGS LR160 Epoxy resin and EPIKURE Curing Agent MGS LH260S Hardener, Epoxy resin/hardener mixture was prepared with a ratio of 100:35. Prepared resin was deposited into the resin bath tank. The process at desired parameters was began by loading the motion codes to machine. After process was completed, a heat shrinkage tape was wrapped on the mandrel and curing procedure was performed by heating the specimens when it was rotating. Sanding and polishing as post processing were conducted to obtain aesthetic appearance on the specimen.

\subsection{Specimens}

Specimens at different design parameters were fabricated to see machine works efficiently and reliably. Different round shapes, winding angles, as shown in Figure 5, aluminum/glass, steel/carbon, carbon/glass and aramid/carbon were obtained for hybrid configurations. Also, single carbon, glass, basalt and aramid (Kevlar) fiber reinforced composite shapes were produced. Relation between linear axis and winding angle can be calculated by using Equation 1 .

$\tan \alpha=\left(\mathrm{N}_{\mathrm{m}} \pi \mathrm{D}\right) / \mathrm{V}_{\mathrm{c}}$

where $\alpha$ and $\mathrm{D}$ represents the winding angle (degree) and diameter of the mandrel, respectively. Also, $\mathrm{V}_{\mathrm{c}}$ and $\mathrm{N}_{\mathrm{m}}$ are used to specify the carriage velocity $(\mathrm{mm} / \mathrm{min})$ and mandrel velocity (rpm), respectively.

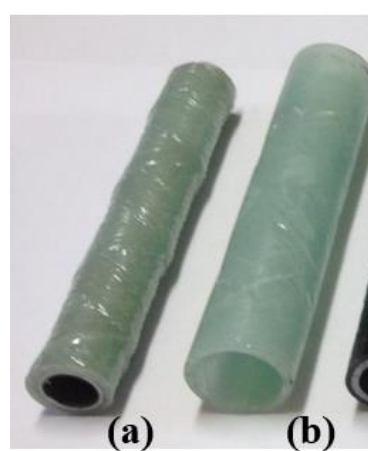

(b)

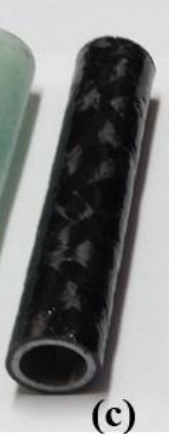

(c)

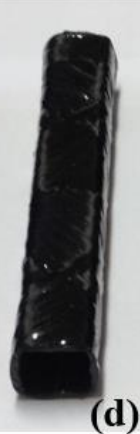

(d)
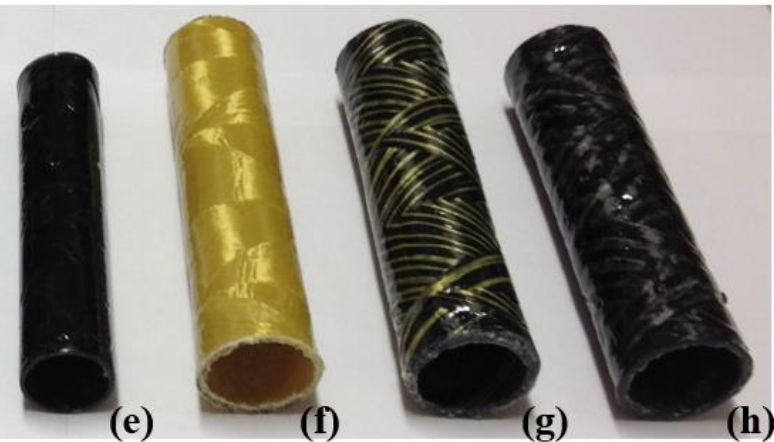

Figure 6. Specimens. (a) Aluminum/glass fiber with $67.5^{\circ}$. (b) Glass fiber with $45^{\circ}$. (c) Steel/carbon fiber with $40^{\circ}$. (d) Carbon fiber with $45^{\circ}$. (e) Basalt fiber with $45^{\circ}$. (f) Aramid (Kevlar) fiber with $50^{\circ}$. (g) Carbon/aramid hybrid fiber with $45^{\circ}$. (h) Carbon/glass fiber with $45^{\circ}$.

Specimens having different cross sections such as hexagon, square and circular were obtained from the filament winding machine. The quality of specimens are acceptable and filament paths are good configurations as seen in Figure 7. After successful fabrications, sanding and polishing were conducted to have good surface quality. Specimen applied the post processing is shown in Figure 8.
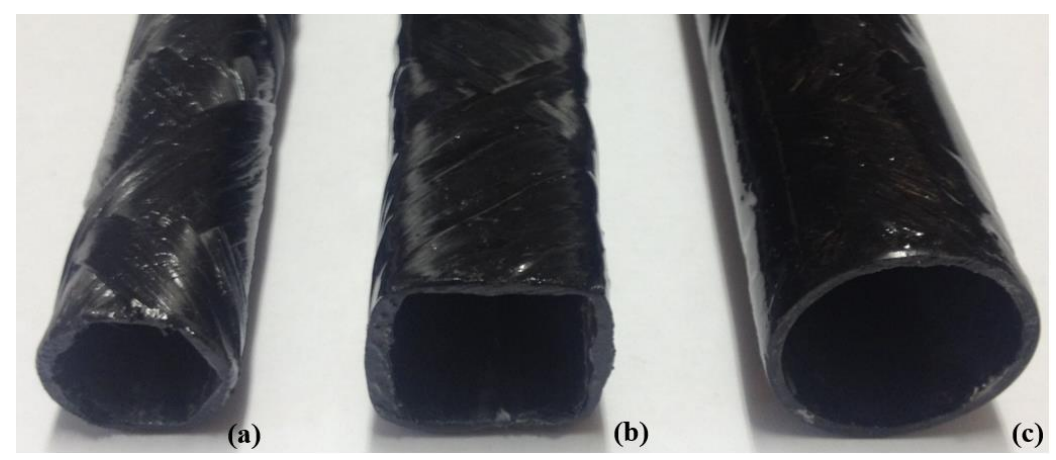

Figure 7. Specimens having different cross sections. (a) Hexagon. (b) Square. (c) Circular. 


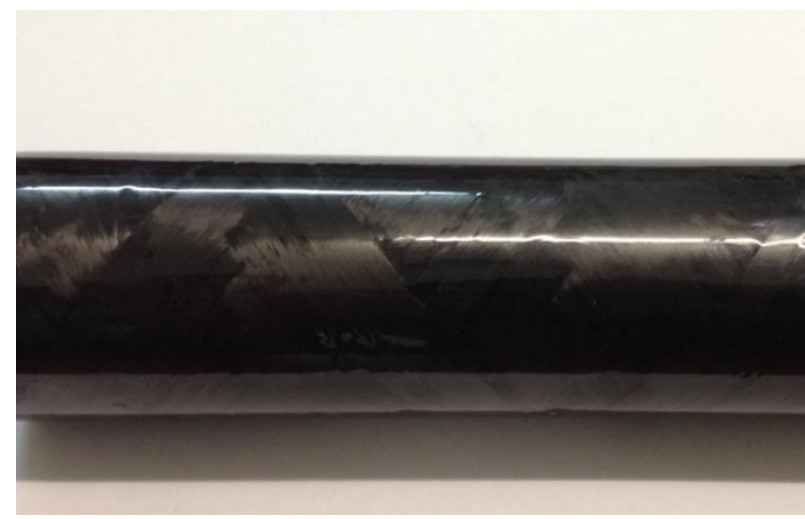

Figure 8. Carbon fiber with $45^{\circ}$ after post processing.

\section{Conclusions}

In this study, a laboratory scale filament winding machine having 2-axis motion was designed and constructed for the fabrication of fiber reinforced composite specimens. The machine has capability for the specimen fabrication at different design parameters such as dimensions up to $750 \mathrm{~mm}$ length and $250 \mathrm{~mm}$ diameter, winding angle for helical, hoop and polar winding types. Also, an algorithm that is written on MATLAB programming environment was developed to obtain motion codes. The fiber reinforced specimens were manufactured according to different fiber reinforcements, hybrid arrangements and cross sections. The constructed machine showed to work well by fabricating the specimens at different design parameters.

\section{References}

Abdalla, F.H., Mutasher, S.A., Khalid, Y.A., Sapuan, S.M., Hamouda, A.M.S., Sahari, B.B. and Hamdan, M.M., 2007. Design and Fabrication of Low Cost Filament Winding Machine. Materials \& Design, 28(1), 234-239.

Bulut, M., 2020. Low-Velocity Impact Tests on Basalt Fiber/Polypropylene Core Honeycomb Sandwich Composites. Mechanics of Composite Materials, 1-10.

Gay, D., 2014. Composite Materials: Design and Applications: NW, CRC Press, Taylor \& Francis Group.

Gemi, L., Morkavuk, S., Köklü, U., \& Gemi, D.S., 2019. An Experimental Study on the Effects of Various Drill Types on Drilling Performance of GFRP Composite Pipes and Damage Formation. Composites Part B: Engineering, 172, 186-194.
Gemi, L., Köklü, U., Yazman, Ş. and Morkavuk, S., 2020. The Effects of Stacking Sequence on Drilling Machinability of Filament Wound Hybrid Composite Pipes: Part-1 Mechanical Characterization and Drilling Tests. Composites Part B: Engineering, 107787.

Imamura, T., Kuroiwa, T., Terashima, K. and Takemoto, H., 1999. Proc. In Systems, Man and Cybernetics, IEEE SMC'99 Conference (IEEE 1999), 12-15, Antalya-Turkey.

Kim, Y.K. and Chalivendra, V., 2020. Natural Fibre Composites (NFCs) for Construction and Automotive Industries. In Handbook of Natural Fibres (pp. 469-498). Woodhead Publishing.

Krishnamurthy, T.N. and Idkan, M., 2014. Fabrication of Low Cost Filament Winding Machine. International Journal of Recent Trends in Electrical \& Electronics Engineering, 4(1), 3039.

Mateen, M.A., Shankar, D.R. and Hussain, M.M., 2018. Design and Development of Low Cost Two Axis Filament Winding Machine. Journal of Advanced Manufacturing Technology (JAMT), 12(1), 117-126.

Mutasher, S., Mir-Nasiri, N. and Chai Lin, L., 2012. Small-Scale Filament Winding Machine for Producing Fiber Composite Products. Journal of Engineering Science and Technology, 7(2), 156168.

Özbek, Ö. and Bozkurt, Ö.Y., 2019. Hoop Tensile and Compression Behavior of Glass-Carbon Intraply Hybrid Fiber Reinforced Filament Wound Composite Pipes. Materials Testing, 61(8), 763769.

Peters, S.T., 2011. Composite Filament Winding: ASM International, Materials Park, Ohio, USA.

Quanjin, M., Rejab, M.R.M., Kumar, N.M. and Idris, M.S., 2019. Experimental Assessment of the 3Axis Filament Winding Machine Performance. Results in Engineering, 2, 100017.

Saad, M.A., 1997. Design and Fabricate Filament Winding Machine and Analysis of Cotton/Epoxy and Pandanus/Epoxy: Master Thesis, Universiti Putra Malaysia. 